\title{
RZECZNIK FINANSOWY - ANALIZA DZIAŁALNOŚCI W ZAKRESIE ALTERNATYWNYCH METOD ROZSTRZYGANIA SPORÓW
}

Piotr Liwoch

Wydział Prawa i Administracji, Uniwersytet Jagielloński, Wydział Finansów i Prawa, Uniwersytet Ekonomiczny w Krakowie

\begin{abstract}
Streszczenie
Artykuł traktuje o stosunkowo nowym podmiocie - Rzeczniku Finansowym - który przede wszystkim podejmuje działania na rzecz ochrony klienta indywidualnego korzystającego z usług podmiotów rynku finansowego. W niniejszej publikacji autor przedstawia, ujętą w ustawie z dnia 5 sierpnia 2015 r. o rozpatrywaniu reklamacji przez podmioty rynku finansowego i o Rzeczniku Finansowym, procedurę postępowania reklamacyjnego, a także podejmuje próbę analizy działalności Rzecznika Finansowego w obszarze alternatywnych metod rozstrzygania sporów oraz przedstawia postulaty w zakresie rozwoju tej instytucji w kolejnych latach. Celem niniejszego artykułu jest porównanie i ukazanie podobieństwa funkcji i zadań Rzecznika Finansowego z Rzecznikiem Ubezpieczonych w kontekście ewolucji instytucji prawnych, a także przedstawienie kompetencji Rzecznika Finansowego w obszarze ADR.
\end{abstract}

Słowa kluczowe: Rzecznik Finansowy, uczestnicy rynku finansowego, postępowanie reklamacyjne, alternatywne metody rozstrzygania sporów.

JEL Class: G21, G22, G23, K29. 


\section{WPROWADZENIE}

W ostatnich latach w polskim systemie prawnym można dostrzec dążenie ustawodawcy do zwiększenia znaczenia alternatywnych metod rozstrzygania sporów (Alternative Disputes Resolution ${ }^{1}$, zwane także ADR). Zmiany te przede wszystkim wprowadzane są w celu skrócenia czasu rozwiązania konfliktu pomiędzy stronami, a także zmniejszenia kosztów postępowania wynikłego ze sporu. Ewolucję zauważyć można $\mathrm{w}$ wielu obszarach prawa, między innymi w prawie cywilnym, gdzie z dniem 1 stycznia 2016 r. weszła w życie, wprowadzająca zasadę nakłaniania stron do mediacji ${ }^{2} \mathrm{w}$ postępowaniu cywilnym, ustawa o zmianie niektórych ustaw w związku ze wspieraniem polubownych metod rozwiązywania sporów [Dz.U. 2015, poz. 1595], czy też ustawa z dnia 7 kwietnia 2017 r. [Dz.U. 2017, poz. 935], nowelizująca Kodeks postępowania administracyjnego, która wprowadziła do postępowania administracyjnego instytucję mediacji. Prowadzenie polubownego postępowania jest także uprawnieniem Rzecznika Finansowego, który został powołany w miejsce stosującego alternatywne metody rozstrzygania sporów Rzecznika Ubezpieczonych, jednak - ze względu na obligatoryjność postępowania przed Rzecznikiem Finansowym dla podmiotu rynku finansowego oraz rozszerzenie tych kompetencji na rynek bankowo-kapitałowy - dysponującego szerszym zakresem uprawnień względem swojego poprzednika.

Celem niniejszej pracy jest przedstawienie procedury postępowania reklamacyjnego przed Rzecznikiem Finansowym, a także analiza rosnącej popularności alternatywnych metod rozstrzygania sporów na przykładzie konfliktów rozwiązywanych przez ten stosunkowo nowy podmiot. Artykuł - na podstawie udostępnianych sprawozdań z działalności Rzecznika - podejmuje próbę oceny skuteczności jego działalności ze szczególnym uwzględnieniem stosowania metod alternatywnego rozwiązywania sporów, a także przedstawienia postulatów w zakresie rozwoju ochrony klienta podmiotów sektora finansowego, biorąc pod uwagę aktywność Rzecznika Finansowego w obszarze ADR. Autor, na podstawie analizy aktów prawnych, artykułów przedstawicieli nauki oraz sprawozdań Rzecznika Finansowego, próbował potwierdzić hipotezę badawczą, że prowadzona przez ten podmiot działalność w zakresie alternatywnych metod rozstrzygania sporów zyskuje na znaczeniu i może nieść istotną pomoc klientom podmiotów rynku finansowego.

${ }^{1}$ Do alternatywnych metod rozstrzygania sporów zalicza się m.in. takie metody jak: mediacja, koncyliacja (która jest często mylnie postrzegana jako mediacja), facyliacja, mini-trial, jurytrial etc.

${ }^{2}$ Zgodnie z definicją podawaną przez Ministerstwo Sprawiedliwości [www1], mediacja jest próbą osiągnięcia satysfakcjonującego rozwiązania sporu przez strony w drodze negocjacji, które są dobrowolne. Negocjacje te prowadzone są przy udziale neutralnej, bezstronnej osoby trzeciej, której celem jest wspieranie przebiegu negocjacji, łagodzenie powstających napięć i pomaganie w dojściu do porozumienia. 


\section{UZASADNIENIE PROJEKTU USTAWY}

Rzecznik Finansowy, który jest następcą prawnym Rzecznika Ubezpieczonych, został powołany do życia ustawą z dnia 5 sierpnia 2015 r. o rozpatrywaniu reklamacji przez podmioty rynku finansowego i o Rzeczniku Finansowym [Dz.U. 2015, poz. 1348 ze zm.]. Zgodnie z uzasadnieniem projektu ustawy [Poselski projekt ustawy o rozpatrywaniu reklamacji..., druk nr 3430], celem jej wprowadzenia było zwiększenie poziomu ochrony osób korzystających z usług sektora finansowego za pomocą uregulowania procesu składania reklamacji, a także dzięki powołaniu instytucji Rzecznika Finansowego.

Zdaniem bowiem projektodawców, akty normatywne dotyczące działalności sektora finansowego nie posiadały regulacji dotyczących terminu oraz sposobu rozpatrzenia reklamacji, z kolei zaś klienci podmiotów rynku finansowego nie mieli możliwości odwołania się od negatywnej decyzji w indywidualnej sprawie wydanej przez taką instytucję, nie wszczynając postępowania sądowego. Na poparcie swojego stanowiska projektodawcy wymienili między innymi braki regulacyjne w takich ustawach, jak: o funduszach inwestycyjnych, o obrocie instrumentami finansowymi, o ubezpieczeniach obowiązkowych, o Ubezpieczeniowym Funduszu Gwarancyjnym. Dodatkowo, ustawa o prawach konsumenta bezpośrednio wyłączała stosowanie przepisów w stosunku do usług finansowych (wykluczone zostały zatem m.in. czynności bankowe, umowy kredytu konsumenckiego, czynności ubezpieczeniowe, uczestnictwo w funduszach inwestycyjnych różnego typu). Brak takich rozwiązań wpływał na poziom ochrony uczestnika sektora finansowego, a także poziom jego zaufania wobec instytucji na nim działających. Szczególnie zauważalna była asymetria panująca pomiędzy podmiotem profesjonalnym a klientem tego podmiotu, który jest konsumentem. Odpowiedzią na rozwiązanie powyższych problemów miało być właśnie unormowanie procesu reklamacji oraz powołanie Rzecznika Finansowego ustawą z 5 sierpnia $2015 \mathrm{r}$.

\section{PROCEDURA REKLAMACYJNA}

Do złożenia reklamacji uprawnieni są klienci podmiotu rynku finansowego (z sektora ubezpieczeniowego, emerytalnego i bankowo-kapitałowego) ${ }^{3}$, którymi są nie tylko konsumenci (w rozumieniu art. $22^{1}$ Kodeksu cywilnego [Ustawa z dnia 23 kwietnia 1964 r..., Dz.U. 1964, nr 16, poz. 93 ze zm.), ale także będące przedsiębiorcami (czyli prowadzące działalność gospodarczą) osoby fizyczne.

${ }^{3}$ Por. art. 1 pkt 1 oraz 3 ustawy o rozpatrywaniu reklamacji przez podmioty rynku finansowego i o Rzeczniku Finansowym. 
Uwagę zwrócić należy także na szerokie rozwinięcie zakresu instytucji ryn$\mathrm{ku}$ finansowego - Rzecznik Ubezpieczonych, zgodnie z ustawą o nadzorze ubezpieczeniowym i emerytalnym oraz Rzeczniku Ubezpieczonych [Dz.U. 2003, poz. 1153 ze zm.] - uprawniony był jedynie do ochrony praw klientów występujących wyłącznie na rynku ubezpieczeniowym. Dzięki rozszerzeniu kręgu podmiotów, ochronę mogą uzyskać nie tylko podmioty obecne na rynku ubezpieczeniowym, ale przede wszystkim te z sektora usług bankowych oraz rynku kapitałowego.

Zgodnie $\mathrm{z}$ ustawą, umowa podmiotu sektora finansowego $\mathrm{z}$ klientem musi zawierać postanowienia określające miejsce i formę złożenia reklamacji, termin jej rozpatrzenia i sposób powiadomienia o rozpatrzeniu. Gdy w umowie nie przewidziano tego typu postanowień, informacje tego rodzaju powinny zostać dostarczone w ciągu 7 dni od dnia zgłoszenia roszczeń. Reklamację klient podmiotu rynku finansowego może złożyć pisemnie (osobiście albo pocztą), ustnie (osobiście do protokołu albo telefonicznie) oraz w formie elektronicznej.

Ustawa także przewiduje termin rozpatrzenia reklamacji. Ustawodawca wyznaczył na takie działanie termin 30 dni od momentu otrzymania reklamacji, ale w skomplikowanym przypadku nadał podmiotowi rynku finansowego uprawnienie do wydłużenia, po odpowiednim uzasadnieniu, wskazanego terminu do 60 dni. Jeżeli podmiot rozpatrujący reklamację nie ustosunkuje się do niej w ustawowo przewidzianym terminie, reklamację uznaje się za rozstrzygniętą w sposób pozytywny.

Poza zwiększonymi terminami w stosunku do terminów reklamacji przysługującej konsumentowi zgodnie z przepisami Kodeksu cywilnego, ustawodawca nałożył także na rozpatrującego reklamację obowiązek uzasadnienia faktycznego i prawnego (od których można odstąpić w przypadku rozpatrzenia reklamacji zgodnie z wolą klienta), a także m.in. obowiązek wyczerpującej informacji na temat stanowiska $\mathrm{w}$ sprawie skierowanych zastrzeżeń. Jeżeli podmiot rozpatruje reklamację w sposób negatywny, musi też zawrzeć informacje odnośnie możliwości odwołania się od tego stanowiska czy też przystąpienia do mediacji, sądu polubownego lub innej metody polubownego rozwiązywania sporów, jeśli przewiduje taką możliwość, a także informować o dopuszczalności wystąpienia z wnioskiem o rozpatrzenie sprawy do Rzecznika Finansowego, albo wystąpienia z powództwem do sądu powszechnego.

Należy zwrócić uwagę na szerokie wymogi informacyjne, które musi spełnić podmiot rynku finansowego nierozpatrujący reklamacji w sposób zgodny z oczekiwaniami klienta. Takie nałożenie obowiązków należy ocenić w sposób zdecydowanie pozytywny, a to ze względu na niską świadomość prawną Polaków. Wydaje się, że rozwiązanie to przez konieczność uzasadnienia faktyczne-

${ }^{4}$ Zgodnie z badaniem „Diagnoza świadomości Polaków 2016” przeprowadzanym na zlecenie Stowarzyszenia Sędziów Polskich Iustitia przez agencję badawczą „Maison\&Partners”, m.in. 
go, prawnego i przedstawienia stanowiska - nie dość, że jest bliskie administracyjnoprawnej zasadzie przekonywania strony ${ }^{5}$, to dodatkowo wymusza na podmiocie sektora finansowego ,pochylenie się" nad indywidualną sprawą zgłaszającego roszczenie. Dodatkowo, zastosowanie uzasadnienia faktycznego i prawnego przypomina formę decyzji administracyjnej, a odwołanie do Rzecznika Finansowego - chociaż nie jest związane $\mathrm{z}$ administracyjnym tokiem instancji jest podobne do postępowania jurysdykcyjnego przewidzianego w Kodeksie postępowania administracyjnego.

\section{POSTĘPOWANIE PRZED RZECZNIKIEM FINANSOWYM}

Rzecznik Finansowy zobowiązany jest do podejmowania działań w zakresie ochrony klientów podmiotów rynku finansowego. Jedną z kompetencji Rzecznika jest m.in. rozpatrywanie wniosków złożonych przez klienta, który nie uzyskał zaspokojenia roszczeń przez instytucję finansową na etapie postępowania reklamacyjnego. Działania te przez Rzecznika Finansowego podejmowane są z urzędu lub na wniosek klienta podmiotu rynku finansowego, właściwego organu nadzorczego, kontroli lub innego organu władzy publicznej (jak np. Komisji Nadzoru Finansowego), a także organizacji konsumenckich w zakresie dystrybucji ubezpieczeń. Po wstępnej kognicji wniosku, badając czy nie nastąpiło naruszenie praw lub interesów klienta, Rzecznik Finansowy będzie uprawniony do podjęcia albo niepodjęcia czynności (w tym drugim wypadku będzie musiał uzasadnić swoje stanowisko), a także ma możliwość wskazania wnioskodawcy przysługujących mu praw i środków działania oraz zasugerowania przeprowadzenia postępowania pozasądowego w zakresie rozstrzygnięcia sporu. Ponadto Rzecznik może występować o udzielenie wyjaśnień lub informacji, postulować o zmianę przepisów w zakresie działalności podmiotów rynku finansowego, przeprowadzać lub zlecać badania odnośnie sytuacji na rynku finansowym, a także - działając na podstawie przepisów dotyczących prokuratora - wytaczać powództwo lub przystępować do toczącego się postępowania na rzecz klientów podmiotu rynku finansowego.

Rozpatrzenie sprawy przez Rzecznika może polegać na:

- poinformowaniu wnioskodawcy, że nie stwierdził naruszenia praw lub interesów,

tylko $36 \%$ badanych jest świadomych, że nieodebrany list polecony z sądu będzie miał skutki formalne, $32 \%$ wie, że testament można odwołać w dowolnej chwili, z kolei 51\% Polaków uważa, że sędzia w Polsce jest członkiem partii politycznej.

${ }^{5}$ Zasada przekonywania strony jest zasadą wynikającą $\mathrm{z}$ art. 11 Kodeksu postępowania administracyjnego. 
- zwróceniu się do podmiotu rynku finansowego o ponowne rozpatrzenie sprawy ze względu na stwierdzenie naruszenia praw lub interesów,

- zwróceniu się do właściwego organu o zbadanie sprawy, w szczególności Komisji Nadzoru Finansowego, Prezesa Urzędu Ochrony Konkurencji i Konsumentów, prokuratury albo innych organów kontroli państwowej, zawodowej lub społecznej.

Poniższe tabele oraz wykresy przedstawiają liczbę złożonych w latach 2015-2017 wniosków do Rzecznika Finansowego o podjęcie czynności, a także ilość czynności podjętych, w tym - rozpatrzonych pozytywnie w obszarze ubezpieczeń gospodarczych oraz rynku bankowo-kapitałowego ${ }^{6}$.

\subsection{Ubezpieczenia gospodarcze}

Tabela 1. Wnioski (skargi) o podjęcie czynności z zakresu ubezpieczeń gospodarczych

\begin{tabular}{|c|c|c|c|}
\hline $\begin{array}{c}2015 \\
(\text { Rzecznik } \\
\text { Ubezpieczonych) }\end{array}$ & $\begin{array}{c}2015 \\
\text { (Rzecznik Finansowy } \\
- \text { od } 11.10 .2015 \text { r.) }\end{array}$ & 2016 & 2017 \\
\hline $\begin{array}{l}\text { Otrzymane: } 11612 \text {, } \\
\text { w tym dotyczące ubez- } \\
\text { pieczeń: } \\
\text { - na życie - } 3141 \\
(27,1 \%) \\
\text { - pozostałe osobowe } \\
\text { i majątkowe - } 8387 \\
(72,2 \%) \\
\text { - brak właściwości - } 84 \\
(0,7 \%)\end{array}$ & $\begin{array}{l}\text { Otrzymane: } 2661 \text {, } \\
\text { w tym dotyczące } \\
\text { ubezpieczeń: } \\
\text { - na życie - } 638 \\
(24 \%) \text {, } \\
\text { - pozostałe osobowe } \\
\text { i majątkowe - } 1425 \\
(53,5 \%) \\
\text { - brak właściwości - } \\
598(22,5 \%)\end{array}$ & $\begin{array}{l}\text { Otrzymane: } 13021, \\
\text { w tym dotyczące } \\
\text { ubezpieczeń: } \\
\text { - na życie - } 4396 \\
(33,7 \%), \\
\text { - pozostałe osobowe } \\
\text { i majątkowe - } 8602- \\
(66,1 \%), \\
\text { - brak właściwości - } \\
23(0,2 \%)\end{array}$ & $\begin{array}{l}\text { Otrzymane: } 14356, \\
\text { w tym dotyczące } \\
\text { ubezpieczeń: } \\
\text { - na życie - } 4859 \\
(33,8 \%), \\
\text { - pozostałe osobowe } \\
\text { i majątkowe - } 9462 \\
(65,9 \%), \\
\text { - brak właściwości - } \\
35(0,3 \%)\end{array}$ \\
\hline
\end{tabular}

Źródło: opracowanie własne na podstawie sprawozdań Rzecznika Finansowego.

Z przedstawionych danych można wywnioskować, że wnioski o podjęcie czynności z zakresu ubezpieczeń gospodarczych są instytucją permanentnie zyskującą na popularności. Wskazać też należy na - spowodowany prawdopodobnie zmianą podmiotu obsługującego skargi w 2015 r. i „testowaniem” zakresu kognicji - duży przyrost wniosków odrzuconych ze względu na brak właściwości. W kolejnych jednak latach ta sytuacja nie pojawiała się $\mathrm{w}$ tak nasilonej postaci.

${ }^{6}$ Ze względu na małą istotność (niską liczbę wniosków), autor pomija obszar zabezpieczeń emerytalnych. 
Decyzje Rzecznika co do podjęcia czynności

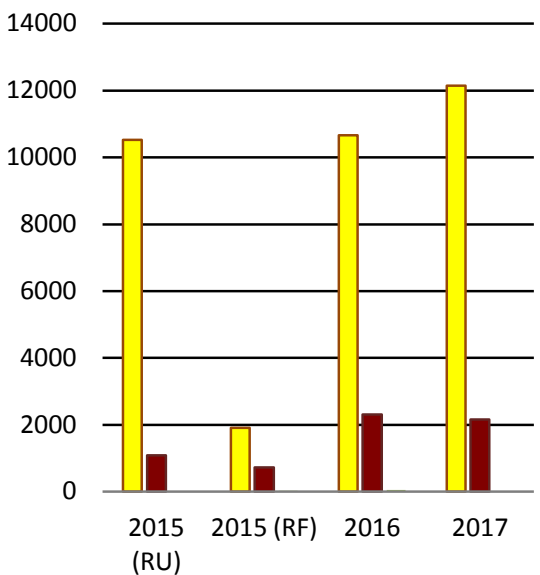

$\square$ Czynności podjęte

- Czynności niepodjęte

- Ponowna analiza wniosku
Struktura decyzji w podjętych interwencjach (\%)

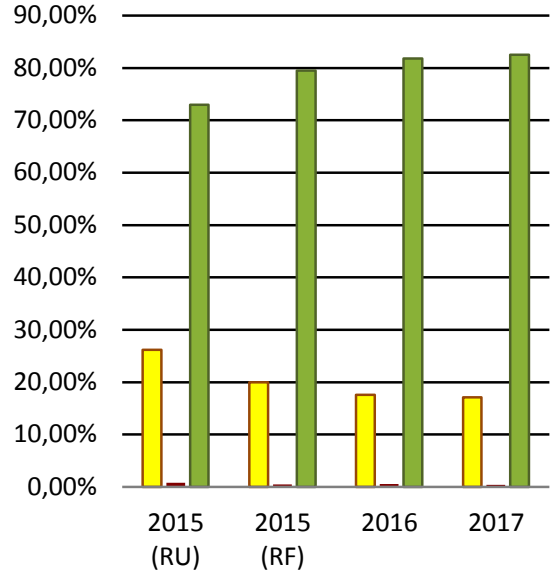

$\square$ Pozytywne

- Uznanie w drodze wyjątku $\square$ Negatywne

Wykres 1 i 2. Odsetek ilości czynności podjętych; struktura decyzji w podjętych interwencjach (\%)

Źródło: opracowanie własne na podstawie sprawozdań Rzecznika Finansowego.

Wskazać przede wszystkim należy, że większość przedstawionych wniosków spełniało jednak wymagania do wszczęcia czynności sprawdzających. Niepokojącym zjawiskiem jest jednak wzrastający odsetek negatywnie rozpatrzonych wniosków - w roku 2017 wyniósł już ponad 80\%.

\subsection{Sektor bankowo-kapitałowy}

Tabela 2. Wnioski (skargi) o podjęcie czynności z zakresu sektora bankowo-kapitałowego

\begin{tabular}{|c|l|l|l|}
\hline \multicolumn{1}{|c|}{$\begin{array}{c}\text { 2015 } \\
\text { (Rzecznik Ubezpieczonych) }\end{array}$} & $\begin{array}{l}\text { 2015 } \\
\text { (Rzecznik Finansowy } \\
\text {-od 11.10.2015 r.) }\end{array}$ & \multicolumn{1}{|c|}{2016} & 2017 \\
\hline $\begin{array}{l}\text { Otrzymane: brak (Rzecznik Ubezpieczo- } \\
\text { nych nie działał w indywidualnej ochronie } \\
\text { klientów tego sektora) }\end{array}$ & Otrzymane: 311 & $\begin{array}{l}\text { Otrzymane: } \\
3916\end{array}$ & $\begin{array}{l}\text { Otrzymane: } \\
4401\end{array}$ \\
\hline
\end{tabular}

Źródło: opracowanie własne na podstawie sprawozdań Rzecznika Finansowego. 
Wnioski o podjęcie czynności z zakresu sektora bankowo-kapitałowego są nową instytucją, która nie występowała na gruncie ustawy o nadzorze ubezpieczeniowym i emerytalnym oraz Rzeczniku Ubezpieczonych. Widać kapitalny wzrost wniosków i mocną tendencję wzrostową w okresie od końca 2015 do końca 2017 roku. Sytuacja ta wynika ze zdominowania instytucji przez wnioski o kredyty hipoteczne denominowane lub indeksowane kursem walut obcych (75\% spraw), co wynika z wzrostu z 136 wniosków w 2016 r. do 1123 takiego typu w 2017 r. (wzrost o 725\%) [Sprawozdanie Rzecznika Finansowego za rok 2017: 36].

Decyzje Rzecznika co do podjęcia czynności

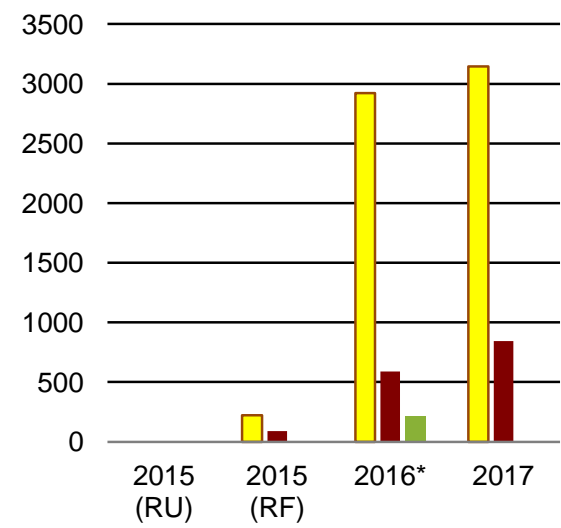

$\square$ Czynności podjęte

- Czynności niepodjęte

- Inne (zła właściwość, brak podstaw, anulowanie sprawy)
Struktura decyzji w podjętych interwencjach**

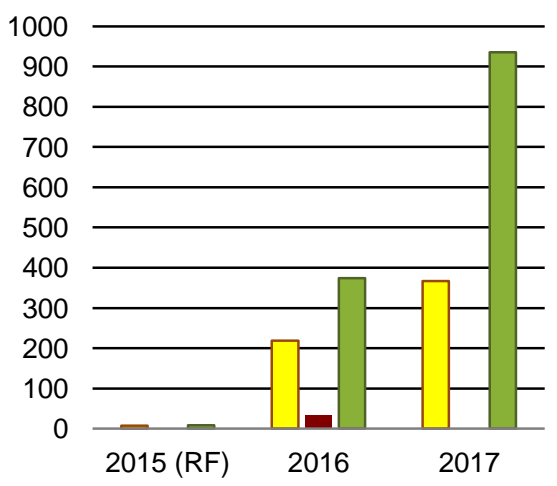

$\square$ Pozytywne

- Częściowo pozytywne

$\square$ Negatywne

* Z 3916 w 2016 r. 3723 wniosków było rozpatrywanych.

** Na koniec roku 2015 było rozpatrzone 15 spraw (w tym 7 pozytywnych), w 2016 r. -627 , 2017 r. -1302.

Wykres 3 i 4. Odsetek ilości czynności podjętych; struktura decyzji w podjętych interwencjach (\%)

Źródło: opracowanie własne na podstawie sprawozdań Rzecznika Finansowego.

Zdecydowana większość złożonych wniosków zakończyła się podjęciem czynności, jednak jeżeli już czynności te zostały podejmowane, to zazwyczaj kończyły się negatywną oceną. Szczególnie różnica dostrzegalna jest w roku 
2017, gdzie 935 wniosków rozpatrzone zostało negatywnie, z kolei tylko 367 - pozytywnie.

Naruszenie praw lub interesów klienta przez podmiot rynku finansowego, polegających na naruszeniu obowiązków informacyjnych albo przekroczeniu terminów związanych z postępowaniem reklamacyjnym, może się wiązać z nałożeniem kary w wysokości nie większej niż 100.000 zł. Kara ta musi być miarkowana w zależności od stopnia naruszenia przepisów, okoliczności tego naruszenia oraz możliwości finansowych podmiotu naruszającego przepisy.

Rzecznikowi Finansowemu ponadto przysługuje uprawnienie do przedstawienia sądowi istotnego dla sprawy poglądu ${ }^{7}$, a także do wytoczenia powództwa przed sądem ochrony konkurencji i konsumentów - Sądem Okręgowym w Warszawie, w zakresie uznania postanowień wzorca umownego za niedozwolone ${ }^{8}$. Ponadto Rzecznik ma prawo przedstawienia wniosku Sądowi Najwyższemu o podjęcie uchwały w przypadku stwierdzenia rozbieżności w orzecznictwie 9 .

W obszarze sektora ubezpieczeniowego w 2015 r. Rzecznikowi Ubezpieczonych zostały złożone 133 wnioski o przedstawienie sądowi istotnego dla sprawy poglądu, a $121 \mathrm{z}$ nich zostało rozpatrzone w sposób pozytywny. Z kolei od 11 października 2015 r. (z tą datą weszła w życie ustawa o rozpatrywaniu reklamacji przez podmioty rynku finansowego i o Rzeczniku Finansowym i doszło do następstwa podmiotowego Rzecznika Finansowego w miejsce Rzecznika Ubezpieczonych) do końca roku 2015, 31 z 39 wniosków złożonych przez klientów podmiotu rynku finansowego zostało przedstawionych sądowi. W 2016 roku już złożono 300 wniosków, a 244 zostały rozpatrzone w sposób pozytywny, zaś w 2017 r. - w 248 przypadkach z 306 wniosków został przedstawiony istotny pogląd $\mathrm{w}$ sprawie.

$\mathrm{Z}$ kolei w zakresie rynku kapitałowego $\mathrm{w}$ roku 2016 pozytywnie zostało rozpatrzonych 97 z 171 wniosków, z kolei w 2017 r. - 242 z 497. Brak jest dostępnych informacji co do liczby wniosków złożonych i rozpatrzonych w tym zakresie w roku 2015.

Należy zwrócić uwagę na ponad dwukrotny wzrost liczby złożonych wniosków na rynku ubezpieczeniowym do Rzecznika Finansowego w roku 2016 względem roku 2015, z kolei w roku 2017 - niewielkie zwiększenie złożonych podań względem roku ubiegłego. Dodatkowo, w latach 2009-2015 do Urzędu Rzecznika Ubezpieczonych wpłynęło tylko 478 wniosków w tym zakresie [Sprawozdanie Rzecznika Finansowego za rok 2015: 90]. Świadczy to przede wszystkim o zyskaniu na

7 Art. 63 Kodeksu postępowania cywilnego [Dz.U. 1964 nr 43 poz. 296 ze zm.] w zw. $\mathrm{z}$ art. 28 o rozpatrywaniu reklamacji przez podmioty rynku finansowego i o Rzeczniku Finansowym.

8 Art. $479^{36}$ Kodeksu postępowania cywilnego [Dz.U. $1964 \mathrm{nr} 43$ poz. 296 ze zm.] w zw. z art. 29 o rozpatrywaniu reklamacji przez podmioty rynku finansowego i o Rzeczniku Finansowym.

9 Art. $60 \$ 2$ ustawy z dnia 23 listopada 2002 r. o Sądzie Najwyższym [Dz.U. 2002 nr 240 poz. 2052 ze zm.]. 
popularności tej formy działania. Ponadto duże znaczenie ma fakt, że wysoki odsetek złożonych wniosków przez klientów podmiotów rynku finansowego jest rozpatrywanych pozytywnie i pomoc Rzecznika jest udzielana.

W roku 2015 Rzecznik Finansowy trzykrotnie kierował do Prezesa Urzędu Ochrony Konkurencji i Konsumentów wystąpienia dotyczące podejrzenia stosowania praktyk naruszających zbiorowe interesy konsumentów celem zastosowania środków nadzorczych i kontrolnych lub rozważenia zasadności wystąpienia do Sądu Ochrony Konkurencji i Konsumentów z powództwem o uznanie postanowień ogólnych warunków umowy za niedozwolone w obrocie z konsumentami. W 2016 takich wystąpień było cztery, z kolei w 2017 r. - dwa.

Na podstawie powyższych danych można stwierdzić, że ze wskazanego uprawnienia Rzecznik Finansowy nie korzysta zbyt często. Niezależnie od tego należy wskazać, że głównym zadaniem Rzecznika jest chronienie indywidualnego interesu klienta podmiotu rynku finansowego, a kierowane wystąpienia w ramach współpracy z Prezesem Urzędu Ochrony Konkurencji i Konsumentów mają charakter uzupełniający, pomagający w eliminowaniu z rynku nieuczciwych praktyk.

Rzecznik Finansowy wystąpił po jednym wniosku w 2015 i 2016 roku do Sądu Najwyższego o podjęcie uchwał usuwających rozbieżności panujących w orzecznictwie sądowym, które ostatecznie potwierdziły stanowisko Rzecznika w kierowanych wystąpieniach. W 2017 roku Rzecznik złożył trzy wnioski. Na dzień sporządzenia artykułu podjęto jedną, częściowo aprobującą stanowisko Rzecznika Finansowego uchwałę.

\section{ALTERNATYWNE ROZWIĄZYWANIE SPORÓW PRZED RZECZNIKIEM FINANSOWYM}

Wśród uprawnień Rzecznika wymienić można, jak zaznaczono powyżej, wskazanie klientowi podmiotu rynku finansowego możliwości przeprowadzenia pozasądowego postępowania dotyczącego rozwiązania sporu. Jest on członkiem sieci FIN-NET, w skład której wchodzi także Sąd Polubowny przy Komisji Nadzoru Finansowego, zajmujący się sporami między konsumentami i instytucjami finansowym podlegającymi nadzorowi Komisji, a także Arbiter Bankowy przy Związku Banków Polskich, rozstrzygający spory dotyczące roszczeń z zakresu niewykonania lub nienależytego wykonania czynności bankowych. $\mathrm{W}$ przeciwieństwie do wymienionych instytucji, postępowanie przed Rzecznikiem Finansowym na skutek wniesienia wniosku przez klienta, jest obligatoryjne dla podmiotu rynku finansowego [Jurkowska-Zeidler 2017: 361-362].

Klient ma możliwość wnioskować o rozstrzygnięcie sporu przez wykorzystanie jednej z metod: mediacji (umożliwienie zbliżenia stanowisk stron w celu rozwiązania sporu przez jego strony) lub koncyliacji (przedstawienie stronom propozycji rozwiązania sporu). W trakcie postępowania Rzecznik przedstawia podmio- 
towi rynku finansowego, który obligatoryjne musi włączyć się w postępowanie, roszczenie klienta, przedstawia stronom przepisy prawa, które znajdują zastosowanie w przedmiotowej sprawie oraz podejmuje czynności mediacyjne lub koncyliacyjne. W przypadku braku osiągnięcia porozumienia pomiędzy stronami i zakończenia rozwiązania sporu w sposób polubowny, Rzecznik sporządza opinię, w której w szczególności przedstawia ocenę prawną stanu faktycznego.

Wniosek o rozstrzygnięcie sporu za pomocą postępowania polubownego może zostać rozpoznany w różny sposób w zależności od tego, czy wszczęto postępowanie polubowne.

W odniesieniu do spraw zakończonych przed rozpoczęciem postępowania wyróżnić można następujące środki: odmowę wszczęcia postępowania przez Rzecznika Finansowego (przedmiot wniosku wykracza poza kategorie sporów objętych właściwością Rzecznika, klient nie wyczerpał drogi postępowania reklamacyjnego, wniosek o wszczęcie postępowania spowoduje uciążliwości dla podmiotu rynku finansowego, zawisłość lub rozstrzygnięcie tego samego sporu między stronami, rozpatrzenie sporu zakłóciłoby działanie Rzecznika, klient nie uiścił opłaty za złożenie wniosku) ${ }^{10}$ a także, wypracowaną w drodze praktyki, instytucję pozostawienia wniosku bez rozpoznania - mimo tego, że nie jest to przewidziane w ustawodawstwie [Sprawozdanie Rzecznika Finansowego za rok 2016: 62]. Środek ten stosuje się w przypadkach, gdy wniosek nie zawierał obligatoryjnych elementów, jak np. oznaczenia stron, jasnego żądania, podpisu, etc.

W sytuacji spraw, odnośnie których wszczęto postępowanie, zakończenie może nastąpić za pomocą ugody, sporządzenia przez Rzecznika Finansowego nieobligatoryjnej dla stron opinii (gdy strony nie dojdą do porozumienia), a także umorzenia postępowania - w sytuacji, gdy klient cofa wniosek albo w przypadku, gdy prowadzenie postępowania z innych przyczyn stało się niemożliwe.

W 2015 r. do Sądu Polubownego przy Rzeczniku Ubezpieczonych wniesiono 25 wniosków. W tamtym okresie udział podmiotu rynku finansowego był fakultatywny - tylko 2 na 25 zakładów ubezpieczeń zgodziło się na wszczęcie postępowania, przy czym - jedna sprawa zakończyła się oddaleniem roszczenia, druga z kolei nie została zakończona na okres złożenia sprawozdania przez Rzecznika. Pozostałe 23 kształtowały się w następujący sposób: 12 - odmowa rozstrzygnięcia sporu przez Sąd Polubowny, 6 - umorzenie postępowania ze względu na nieusunięcie braków formalnych albo brak odpowiedzi zakładu ubezpieczeń, z kolei 5 - przyczyny inne, w tym ugoda albo odrzucenie wniosku. W sprawozdaniu Rzecznika Finansowego za rok 2015 nie jest wyszczególnione, na czym polegała wymieniona $w$ innych przyczynach ugoda, ale skoro nie jest

${ }^{10}$ Do 10 stycznia 2017 r. przesłanki te były fakultatywne; Rzecznik, mimo ich wystąpienia, mógł wszcząć postępowanie. Od tamtej pory odmowa wszczęcia postępowania jest obligatoryjna w przypadku wystąpienia którejkolwiek z przesłanek. 
uwzględniona $\mathrm{w}$ postępowaniach wszczętych za zgodą zakładu ubezpieczeń, należy domniemywać, że jest to ugoda zawarta poza postępowaniem z udziałem Rzecznika Ubezpieczonych.

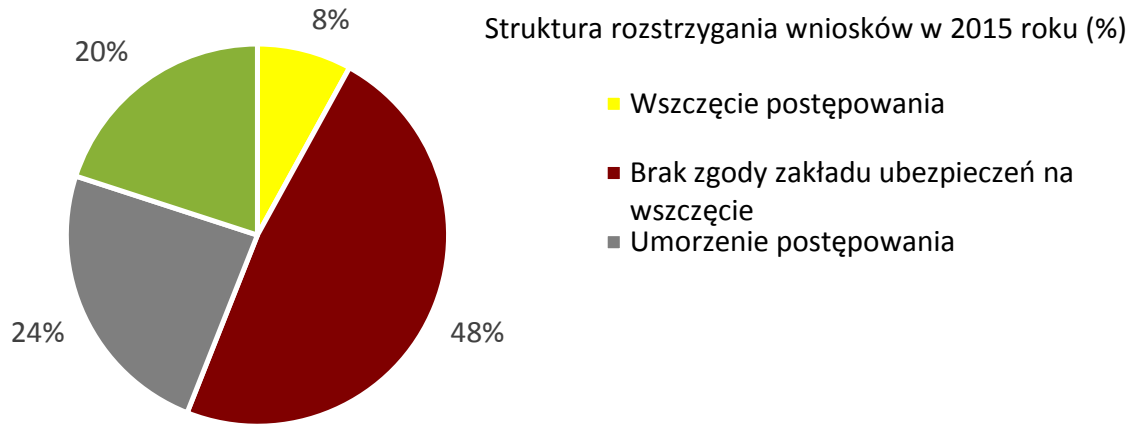

Wykres 5. Struktura rozstrzygania wniosków w 2015 roku (\%)

Źródło: Opracowanie własne na podstawie sprawozdań Rzecznika Finansowego.

Niestety, chociaż brak w sprawozdaniu postępowań przeprowadzonych przez Rzecznika Finansowego w 2015 roku, można wskazać, że w 2016 r. udział przekształconego Sądu Polubownego - w Wydziale Pozasądowego Rozwiązywania Sporów - zmienił się diametralnie. W 2016 r. bowiem złożone zostało 2388 wniosków, z tego 1671 postępowań zostało wszczętych.

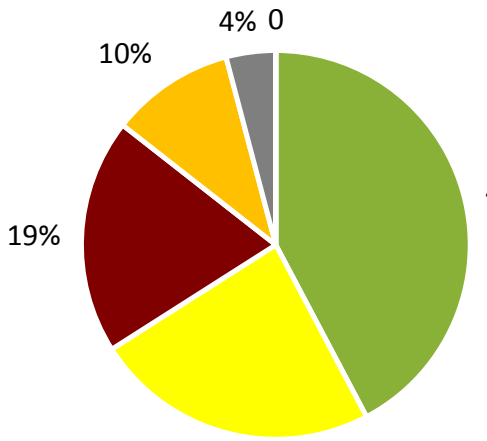

$23 \%$
Struktura rozstrzygania wniosków 2016 roku (\%)

$41 \%$

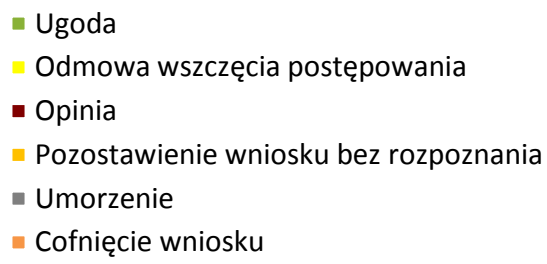

Wykres 6. Struktura rozstrzygania wniosków w 2016 roku (\%)

Źródło: opracowanie własne na podstawie sprawozdań Rzecznika Finansowego.

Jak widać na powyższym wykresie, $60 \%$ wniosków zostało rozstrzygnięte w sposób merytoryczny - osiągnięto ugodę albo opinię Rzecznika. Prawie co czwarty wniosek nie ma nadanego dalszego biegu przez odmowę wszczęcia 
postępowania, co jest najprawdopodobniej powiązane $\mathrm{z}$ wnioskowaniem o wszczęcie postępowania spraw, które wykraczają poza zakres kognicji Rzecznika Finansowego.

79\% wniosków było złożone o wszczęcie postępowania polubownego z zakładami ubezpieczeń, 18\% - bankami, a 3\% - dotyczyły innych podmiotów (rynku kapitałowego).

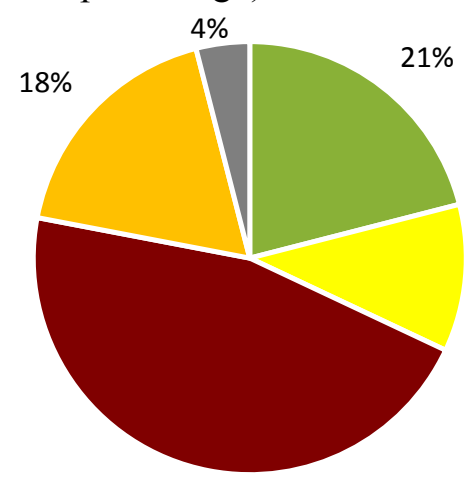

$46 \%$
Struktura rozstrzygania wniosków w 2017 roku (\%)

- Ugoda

Odmowa wszczęcia postępowania

- Opinia

- Pozostawienie wniosku bez rozpoznania

- Umorzenie

Wykres 7. Struktura rozstrzygania wniosków w 2017 roku (\%)

Źródło: Opracowanie własne na podstawie sprawozdań Rzecznika Finansowego

W 2017 roku zostało złożone blisko dwa razy więcej wniosków (3741) względem roku 2016. 60\% wniosków dotyczyło spraw ubezpieczeniowych, 40\% - spraw z zakresu sektora bankowo-kapitałowego (w tym 75\% w sprawach kredytów walutowych). W sposób merytoryczny zostało rozpatrzone 66\% z 2007 spraw zakończonych w 2017 roku. Należy zwrócić uwagę na spadek podejmowanych ugód pomiędzy stronami z $41 \%$ do $21 \%$. Powiązane jest to z ponad pięciokrotnym wzrostem zakończonych spraw w 2017 względem roku ubiegłego, a także $\mathrm{z}$ niechęcią - uczestniczących w postępowaniu przed Rzecznikiem Finansowym tylko ze względu na jego obligatoryjność - podmiotów rynku bankowego [Sprawozdanie Rzecznika Finansowego za rok 2017: 34].

\section{PODSUMOWANIE}

Uwzględniając zmiany w ustawodawstwie pod względem całościowym, zastąpienie Rzecznika Ubezpieczonych instytucją Rzecznika Finansowego należy ocenić pozytywnie.

Rozszerzenie zakresu ochrony klientów podmiotów rynku finansowego o nowe obszary (sektor bankowo-kapitałowy), a także uregulowanie postępowania 
reklamacyjnego z nałożeniem na te podmioty wysokich wymogów informacyjnych sprzyja ochronie konsumenta oraz ogranicza nieuczciwe praktyki rynkowe.

Uwagę także należy zwrócić na wzrastającą co roku ilość złożonych wniosków o podjęcie czynności przez Rzecznika Finansowego i wysoki odsetek podjętych czynności w stosunku do czynności niepodjętych. Niepokojące jest jednak zjawisko bardzo wysokiej ilości negatywnych decyzji rozpatrzonych w skutek przeprowadzonego postępowania; należy jednak mieć nadzieję, że w przyszłości - także poprzez poznanie przez konsumentów tendencji rozstrzygania spraw przez Rzecznika - odsetek decyzji pozytywnych będzie wzrastał.

Pozytywnym zjawiskiem jest (kontynuowana na gruncie ustawy o Rzeczniku Finansowym) możliwość instytucjonalnego wsparcia w postępowaniu cywilnym przez Rzecznika poprzez przedstawienie istotnego poglądu dla sprawy. W ubiegłych latach Rzecznik Finansowy chętnie z tego uprawnienia korzystał, przedstawiając sądowi swój pogląd w większości spraw, co do których zostały złożone wnioski.

Jeśli zaś chodzi o obszar ADR, uwagę przede wszystkim zwraca ilość złożonych wniosków o rozpoczęcie postępowania w zakresie polubownego rozwiązania sporu. Szczególnie pozytywnie należy ocenić obowiązek obligatoryjnego udziału w postępowaniu polubownym przez podmiot rynku finansowego. Uczestnictwo jednak w takim postępowaniu, niestety, nie musi być aktywne, co skutkuje niechęcią podmiotów rynku finansowego do podjęcia rokowań. Takie nastawienie możemy dostrzec przede wszystkim w obszarze kredytów walutowych sektora bankowo-kapitałowego, co w głównej mierze spowodowało spadek podejmowanych ugód między stronami z 41\% w 2016 roku do $21 \% \mathrm{w}$ roku 2017. Próbą rozwiązania takiego stanu rzeczy mogłoby być nałożenie na podmiot rynku finansowego dodatkowego wymogu aktywnego uczestnictwa w polubownym rozstrzyganiu sporu, np. poprzez wprowadzenie zasady aktywnego udziału stron w postępowaniu (gdzie klient podmiotu rynku finansowego - jako strona wnioskująca o podjęcie postępowania - byłby już z samego założenia stroną aktywną), albo obowiązek obligatoryjnego przedstawienia propozycji rozwiązania sporu przez podmiot rynku finansowego.

Niezależnie od tego, instytucję obligatoryjnego uczestnictwa podmiotów rynku finansowego w polubownym rozstrzyganiu sporów przed Rzecznikiem Finansowym $\mathrm{w}$ porównaniu z postępowaniem przed Rzecznikiem Ubezpieczonych (wszczęcie 2 z 25 postępowań, czyli 8\% w 2015 r. wobec 2564 z 3741 , czyli $68,5 \%$ w roku 2017), jak i samą zmianę w obrębie ochrony klienta indywidualnego na rynku finansowym, należy ocenić zdecydowanie pozytywnie. Dzięki takiemu rozwiązaniu klienci podmiotów rynku finansowego mają pewność, że w wypadku konfliktu z takim podmiotem zostanie im udzielona profesjonalna i niezależna pomoc. Należy zatem mieć nadzieję, że instytucja Rzecznika Finansowego zostanie w przyszłości spopularyzowana. 


\title{
BIBLIOGRAFIA
}

Jurkowska-Zeidler A., 2017, Rzecznik Finansowy: Nowa instytucja ochrony klienta na rynku uslug finansowych, Gdańskie Studia Prawnicze, Tom XXXVIII, Gdańsk.

Poselski projekt ustawy o rozpatrywaniu reklamacji przez podmioty rynku finansowego i o Rzeczniku Finansowym (druk nr 3430).

Ustawa z dnia 5 sierpnia 2015 r. o rozpatrywaniu reklamacji przez podmioty rynku finansowego i o Rzeczniku Finansowym, Dz.U. 2015, poz. 1348 ze zm.

Ustawa z dnia 7 kwietnia 2017 r. o zmianie ustawy - Kodeks postępowania administracyjnego oraz niektórych innych ustaw, Dz.U. 2017, poz. 935.

Ustawa z dnia 10 września 2015 r. o zmianie niektórych ustaw w związku ze wspieraniem polubownych metod rozwiązywania sporów, Dz.U. 2015, poz. 1595.

Ustawa z dnia 17 listopada 1964 r. Kodeks postępowania cywilnego, Dz.U. 1964 nr 43 poz. 296 ze zm.

Ustawa o 22 maja 2003 r. nadzorze ubezpieczeniowym i emerytalnym oraz Rzeczniku Ubezpieczonych, Dz.U. 2003, poz. 1153 ze zm.

Ustawa z dnia 23 kwietnia 1964 r. Kodeks cywilny, Dz.U. 1964 nr 16 poz. 93 ze zm.

Ustawa z dnia 23 listopada 2002 r. o Sądzie Najwyższym, Dz.U. 2002 nr 240 poz. 2052 ze zm.

Sprawozdanie Rzecznika Finansowego za rok 2015, https://rf.gov.pl/files/22297_5306_Sprawozdanie_Rzecznika_Finansowego_za_rok_2015.pdf.

Sprawozdanie Rzecznika Finansowego za rok 2016, https://rf.gov.pl/files/22558_5312_Sprawozdanie_Rzecznika_Finansowego_za_2016_r__.pdf.

Sprawozdanie Rzecznika Finansowego za rok 2016 - tabele, https://rf.gov.pl/files/22560_5313_Sprawozdanie_Rzecznika_Finansowego_za_2016_r__tabele.pdf.

Sprawozdanie Rzecznika Finansowego za rok 2017, https://rf.gov.pl/sprawy-biezace/Sprawozdanie_Rzecznika_Finansowego_za_2017_r__22779.

[www1] https://www.ms.gov.pl/pl/dzialalnosc/mediacje/

\section{FINANCIAL OMBUDSMAN - ANALYSIS OF ACTIVITIES IN THE FIELD OF ALTERNATIVE DISPUTES RESOLUTION}

\begin{abstract}
Article presents the institution of Financial Ombudsman, who takes actions for benefit of the financial services market's clients. Author sets out with the aim of presenting complaining procedure and analyzing present activities of Financial Ombudsman and future possible changes in Alternative Dispute Resolution sector.
\end{abstract}

Keywords: Financial Ombudsman, financial market participants, complaint procedure, alternative disputes resolution. 